\title{
EDUCATION IN THE FIELD OF ENERGY EFFICIENCY IN SERBIA - SURVEY RESULTS AND ANALYSIS
}

\author{
Bojana Jovanović* \\ Iritel a.d. Belgrade, Serbia \\ Dr Vojislav Božanić \\ University of Belgrade, Faculty of organizational science, Belgrade, Serbia \\ Bojan Jovanović \\ University of Belgrade, Faculty of electrical engineering, Belgrade, Serbia
}

In the Balkan region and in the territory of the Republic of Serbia, the energy consumption in relation to gross domestic product is huge. The Republic of Serbia consumes two to three times more energy than the gross domestic product, compared with the average in the European Union. At the beginning of 2013, on the territory of the Republic of Serbia, will be announced the Law on rational use of energy, which is currently in draft form. Adoption of the Law is a step in Serbia's accession to the EU, because the Law will basically have taken a European directive on energy efficiency. In order to determine the extent to which the concept of energy efficiency is presented in the formal and informal education, as well as knowledge of this area in general, the survey was done. This paper describes a results of survey that was done with the aim of gaining information about education in the field of energy efficiency in formal and informal education systems in Serbia, as well as how much are the citizens familiar with the term. This paper shows the questionnaire which was distributed to the respondents. For easily and quickly collecting the necessary data, it was used the on-line questionnaire. The questionnaire was designed as a web application. The survey was conducted on a sample of 200 respondents, from September to December 2012. After the structure of the respondents, the results of research and analysis are presented in this paper, with one proposed research in future.

Key words: Energy efficiency, Education, Survey

\section{INTRODUCTION AND LITERATURE REVIEW}

In improvement of energy efficiency, education of people plays the most important role. Topic of energy efficiency in extremely increasing: in 2010 there are 41,833 papers about energy efficiency, in 2011 51,427 papers, in 2012 59,029 papers, 24,780 papers accepted for publication and publicated paper in 2013 and one paper accepted for publication i 2014 [10].

There are some papers which deal with specific fields of energy efficiency. Santos, Faga \& Santos (2013) discussed the impact of different approaches through a case study on the regulations of energy efficiency for buildings in four countries: Brazil, China, India and Russia [16]. Gunn (1997) analyzed the interactions between the concepts of energy efficiency and economic efficiency [07]. Momčilović, Medar, Manojlović \& Papić (2003) analyzed energy efficiency as one element in development of information system in transportation company [15]. Mandal (2010) estimated energy use efficiency in the presence of energy related undesirable emission by taking Indian cement industry as a suitable context of analysis [14]. Griffin, Hammond, Ng \& Norman (2012) presented a bottom-up/top-down data analysis to examine the influence of the scheme on the overall energy demand trend of the UK industrial sector as separated from structural and output effects [06]. Fleiter, Fehrenbach, Worrell \& Eichhammer (2012) analyzed improvements in energy efficiency in the German pulp and paper industry up to 2035 using a techno-economic approach [05]. Cagno, Worrell, Trianni \& Pigliese (2013) provided a novel approach for barriers to the adoption of industrial energy-efficient technologies [03]. Al-Mansour (2011) analysed the structure, trends of energy consumption and energy efficiency indicators by sectors of economic 
activity in Slovenia [01]. Lopes, Antunes \& Martins (2012) presented a review on energy behaviours in order to recognise recent trends, quantify energy behaviours potential savings, characterise energy behaviour modelling strategies and identify potential research gaps. Energy behaviours have a crucial role in promoting energy efficiency, but energy behaviours characteristics and complexity create several research challenges that must be overcome so energy behaviours may be properly valorised and integrated in the energy policy context [13]. Backlund, Thollander, Palm \& Ottsson (2012) introduced an extended energy efficiency gap, mainly in manufacturing industries and the commercial sector [02]. The inclusion of energy management components in future energy policy will play an important role if the energy savings targets for 2020, and later 2050, are to be met in the EU.

There is one study about relationship of energy efficiency and human behavior and education. Sola \& Xavier (2007) presented a study accomplished in the State of Parana in Southern Brazil, aiming at verifying the correlation between organizational human factors and the level of energy losses in organizations. They determined that management system, education of employees and strategical vision has an important influence on energy efficiency [17].

\section{PROBLEM OVERVIEW}

The importance of energy for the development of economy and society contribute to energy policy development in each country [04]. In the Balkan region and in the territory of the Repub-

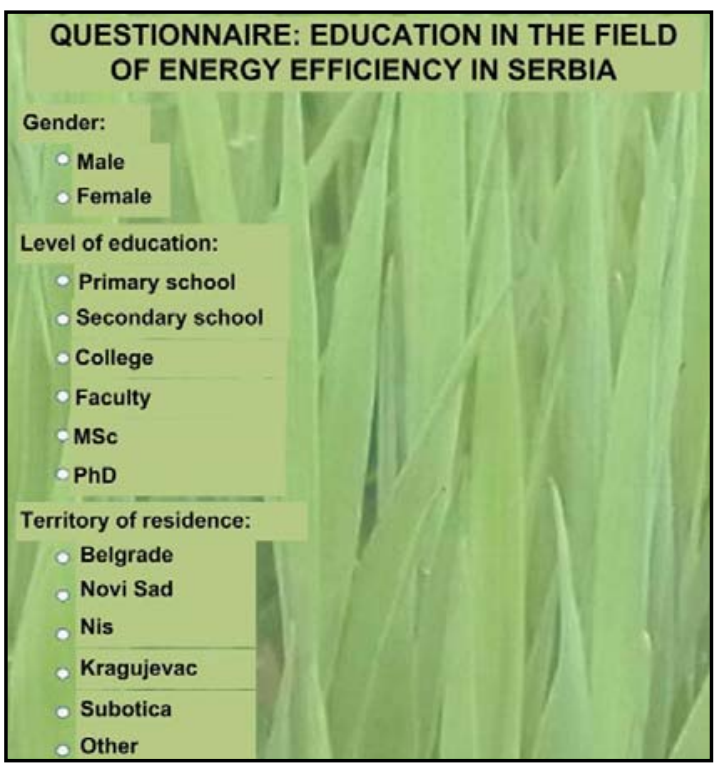

lic of Serbia, the energy consumption in relation to gross domestic product is huge. The Republic of Serbia consumes two to three times more energy than the gross domestic product, compared with the average in the European Union [09]. In addition to the lack of funds for investment in energy-efficient equipment and technology, a special challenge is the lack of awareness of citizens and companies about the benefits of investing in energy efficiency. As for most of the socio-economic problems, education is a maner for achieving the improvement, both in formal educational institutions (primary and secondary schools, universities) and through non-formal education, which is very important.

In order to determine the extent to which the concept of energy efficiency is presented in the formal and non-formal education, as well as knowledge of this area in general, the survey was done. The survey was conducted on a sample of 200 respondents of different gender, education level, place of residence, etc. The survey was conducted from September to December 2012. This paper presents the results and analysis of the survey.

\section{CREATION AND DISTRIBUTION OF QUESTIONNAIRE}

For easily and quickly collecting the necessary data, it was used the on-line questionnaire. The questionnaire was designed with the help of free on-line application, written by one of the authors [08]. Part of the questionnaire, which was distributed to participants in the survey, has the following format (print screen):

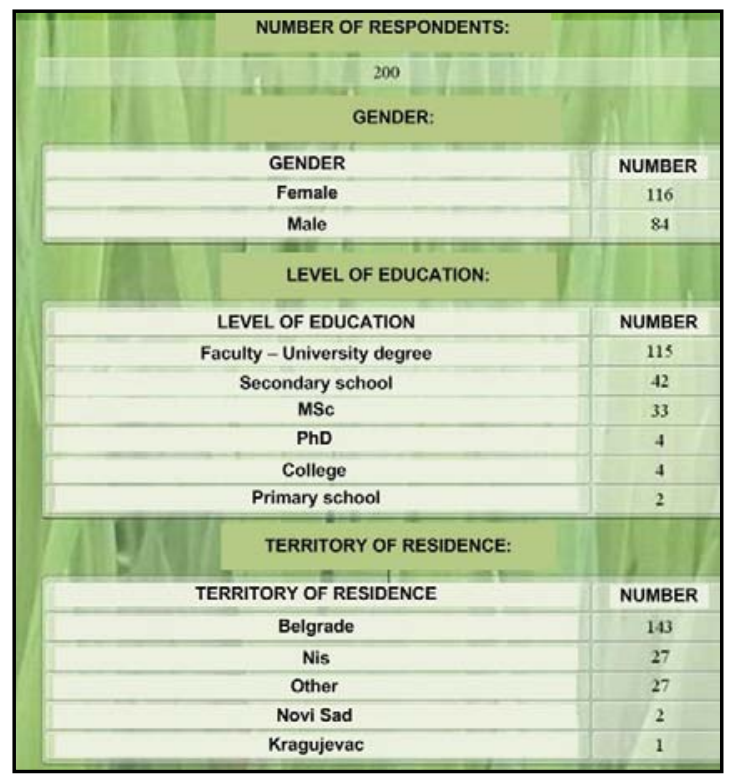

Figure 1 and 2: Part the questionnaire and statistics of answers 


\section{RESULTS AND ANALYSIS}

\section{1) Gender of respondents}

The gender structure of the respondents is showed in this part of the analysis of the results. The sample was representative in terms of gender of respondents, because the overall structure represented $58 \%$ of female and $42 \%$ male respondents. The following graphic shows the structure of the respondents.

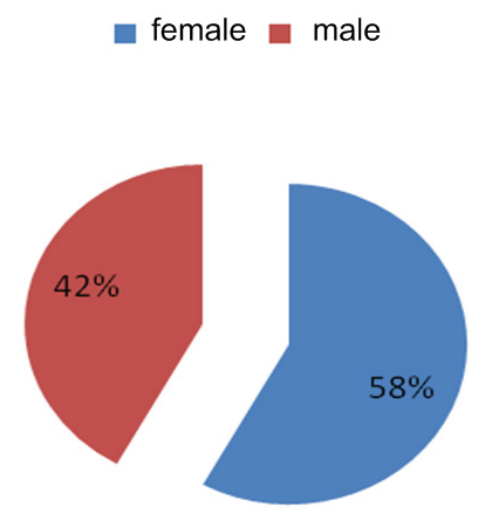

Figure 3: Structure of respondents - gender

\section{2) Level of education}

The structure of the respondents, according to the level of their education, is shown in this part of the analysis of the results. The survey included respondents with primary schools, high schools, colleges and university graduates (BSc, $\mathrm{MSc}, \mathrm{PhD}$ ). In relation to the level of education of the respondents, it can be concluded that the research involved different groups of respondents, according to the level of education. Thus, the sample of respondents is representative from this point of view. The following graphic shows the structure of respondents by education level.

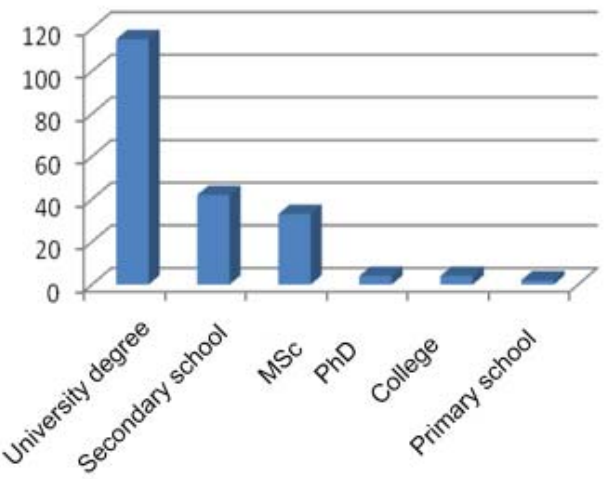

Number of respondents

Figure 4: Structure of respondents - level of education

\section{3) Territory of residence}

This part of the analysis of the results shows the structure of the respondents to the territory of their residence. The aim was to include respondents with different territories, because not all of the territory of Serbia has the same access to information and education in the field of energy efficiency. As can be seen in the structure of respondents, the respondents have a place of residence in different territories (cities) in Serbia, and then the sample is representative. The following graphic shows the territorial distribution of the respondents.

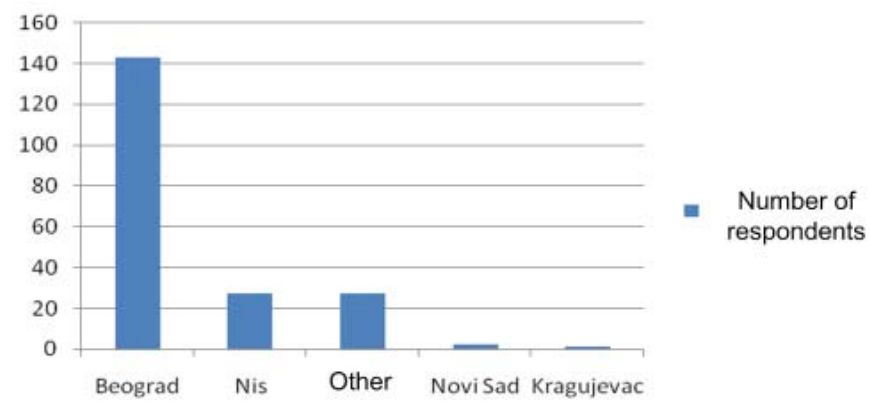

Figure 5: Structure of respondents - territory of residence

4) Knowing the meaning of the term "energy efficiency"

According to standard ISO 50001 [11], which provides the requirements for energy management systems, energy efficiency is defined as the ratio of quantitative or quantitative relation between output performance, service, goods or energy, and the energy input. When respondents were asked if they know the meaning of the term "energy efficiency", the majority of respondents (127 respondents) answered that fully knows the meaning of the term "energy efficiency", 68 respondents said that heard for the term but did not know what it means, and only 5 respondents have never heard for term "energy efficiency".

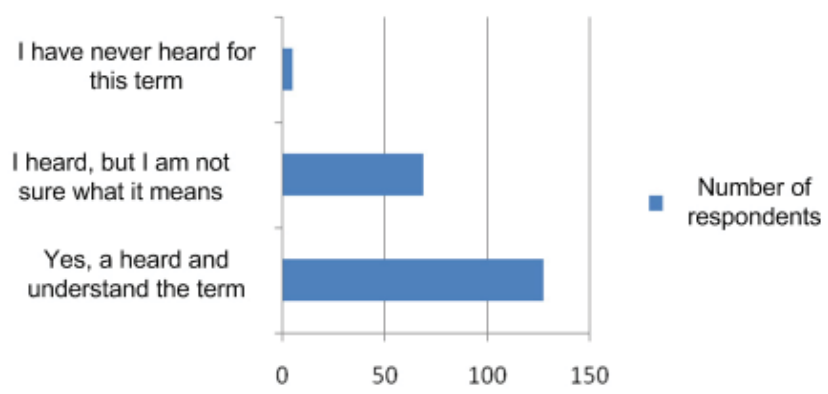

Figure 6: Knowing the meaning of the term "energy efficiency"

5) The presence of energy efficiency as a topic within formal education (primary school, secondary school, college, faculty)

Formal education systems are extremely impor- 
tant in the development of people's awareness on rational use of energy and conservation of the environment in general. Respondents were asked if they had a subject about energy efficiency in formal education. Most respondents have never had subject about energy efficiency in formal education (158 respondents), and only 42 respondents said that during a formal education encountered on the concept of energy efficiency. It was not analyzed how this concept thoroughly addressed in these subjects. The following graphic shows a graphical analysis of received responses.

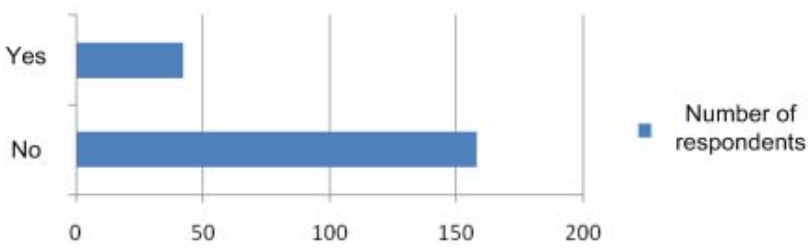

Figure 7: Presence of energy efficiency as a topic within formal education

The survey led to the data about schools/faculties in Serbia which have subjects related to energy efficiency. We hope that this list is not definitive, and certainly there are some educational institutions that deal, dealt with or have plans about these subjects:

- Social responsibility (Faculty of Organizational Sciences, Belgrade)

- Sustainable development (Faculty of Organizational Sciences, Belgrade)

- Environmental management (Faculty of Organizational Sciences, Belgrade)

- Environmental management systems (Faculty of Organizational Sciences, Belgrade)

- Technology and development (Faculty of Organizational Sciences, Belgrade)

- Ecology (Faculty of Organizational Sciences, Belgrade)

- The management of natural and cultural resources (Faculty of Tourism and Hospitality Management in Tourism, Belgrade)

- Geography (Valjevo Gymnasium, Valjevo)

- Town sociology (Faculty of Arts, Belgrade)

- Power electronics (Faculty of Electrical Engineering, Belgrade)
- Transformers (Faculty of Electrical Engineering, Belgrade)

- Power system analysis (Faculty of Electrical Engineering, Belgrade)

- Power (Faculty of Electrical Engineering, Belgrade)

- Technical education (Elementary School)

- Ecology (Elementary School)

- Heating and air conditioning (Faculty of Mechanical Engineering, Belgrade)

- Energy processes and environment (Faculty of Occupational Safety, Niš)

- Utility systems and environment (Faculty of Occupational Safety, Niš)

- Sustainable development (Faculty of Occupational Safety, Niš)

- Industrial ecology (Faculty of Occupational Safety, Niš)

- Thermal power processes (Faculty of Occupational Safety, Niš)

- Energy (Faculty of Occupational Safety, Niš).

6) Frequency of meetings visits, forums visits, conferences visits, etc. (informal education) with the subject of energy efficiency

Informal education systems also have an important role in developing and maintaining awareness of the rational use of energy. This type of education is often focused on the population of a higher level of education. Respondents were asked if they have ever visited meetings, seminars, conferences, forums, etc. with the subject of energy efficiency and renewable energy sources. The majority of respondents (141) said they have never visited seminars like this, 30 respondents were on one conference with this subject, 26 respondents were several times, and only 3 respondents regularly visit these conferences. Graphical analysis of the results is shown below.

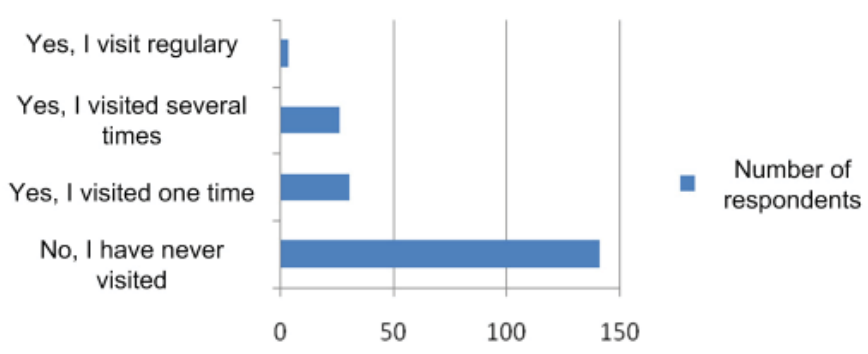

Figure 8: Frequency of meetings visits, forums visits, conferences visits, etc. 
7) Familiarity with the legislation and standardization in the field of energy efficiency (the Law on the rational use of energy, energy passports for buildings, standard ISO 50001, etc.)

Innovation in terms of legislation in this field, which is expected in the Republic of Serbia is a publication of the Law on the rational use of energy [12], and translated version of the International Standard ISO 50001. With the publication of the Regulations concerning energy efficiency in buildings, almost every building is subject to these rules. The obligation to obtain energy passports for building affects both companies and private households. Energy labeling class of electronic devices will also be a liability for manufacturers. For all these reasons it is important to be familiar with the legislation promptly, enabling the timely and appropriate application. Law on the rational use of energy in Serbia is in the draft form. Its publication is expected in early 2013. The Law would be obligatory for all large energy consumers, energy producers and all public and state enterprises and organizations. Organizations will have obligation to establish and maintain an energy management system, to monitor consumption and reported to the authorities. The Law also sets out the requirements for class of energy labeling of electronic devices. Standard ISO 50001 provides requirements for establishing, implementing and maintaining the energy management system.

Question posed to respondents was if they have ever heard about the new legislation and standards in the field of energy efficiency (energy passports for buildings, the Law on rational energy use, standard ISO 50001, etc.) and are they familiar with the requirements of these documents. 96 respondents said they had heard but did not understand the requirements of these documents, 79 of respondents have not heard for these documents, and 25 respondents were fully aware of the requirements. Graphical analysis of the results is shown below.

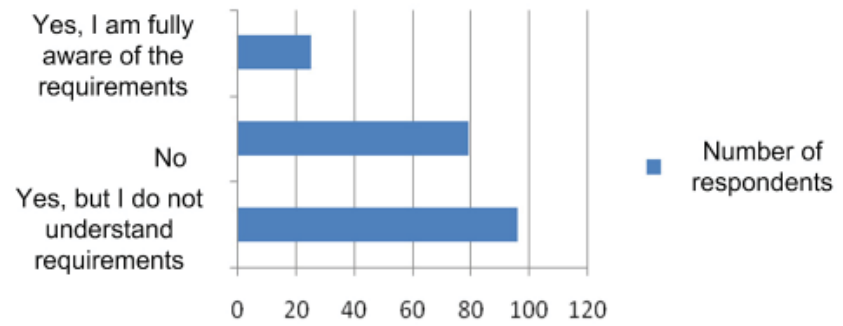

Figure 9: Familiarity with the legislation and standards in the field of energy efficiency

Journal of Applied Engineering Science 11(2013)1, 245

\section{8) Familiarity with various sources of renewable energy}

Application of renewable energy and the use of cleaner energy instead of traditional fossil fuels, significantly reduced the environmental pollution. There are different sources of renewable energy. Whether they are more or less available, more or less used, they are very important, because they enable the preservation of natural resources. In contrast to the limited natural resources, renewable energy sources are unlimited and available to everyone. Some of the most important and widely used renewable energy sources are: solar energy, wind energy, geothermal energy, hydropower, fuel cells and biomass. Solar energy is the energy of solar radiation in the form of light and heat. Wind energy is the energy that comes from wind power. Hydropower is the power received from the generation from the water. The term geothermal energy refers to the use of heat inside of the Earth, which is at the center approximately $4000-7000^{\circ} \mathrm{C}$, which is approximately the temperature of the Sun's surface. Biomass refers to matter plant or animal origin, which can be used as fuel or for industrial production. Fuel cells are electrochemical cells that generate electricity from the energy released by chemical reaction of fuel continually leads with oxidizing agents.

Using the questionnaire, the authors wanted to determine awareness of respondents about the existence of various forms of renewable energy. In the analysis it was not determined the level of familiarity with some of the renewable energy sources. The survey only included analysis of are respondents heard about the renewable energy sources that are listed in the questionnaire. The question was: Which forms of renewable energy are you familiar with? The largest number of respondents (197) had heard for solar energy, 194 respondents for wind energy, 161 respondents for water energy, 134 for geothermal energy, 99 for biomass, and only 57 respondents had heard for fuel cell. Graphical analysis of the results is shown below.

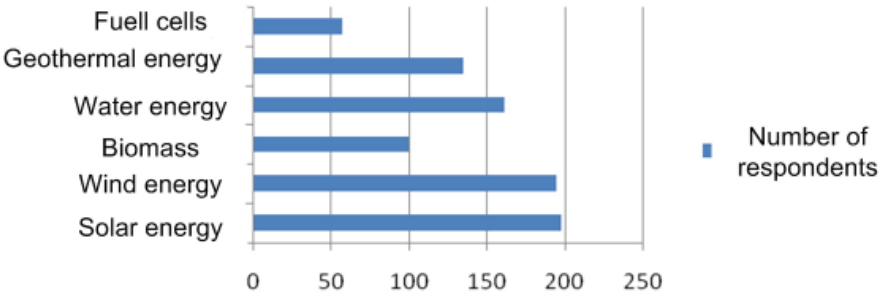

Figure 10: Familiarity with various sources of renewable energy 
9) Respondents opinion about factors which the most effect on energy efficiency

In this section of paper, it was determined what the respondents think about which factor has the biggest impact on energy efficiency. The question was: In your opinion, which of the following factors have the biggest impact on energy efficiency? 74 respondents said that the most affects technologies and technical solutions, 67 of the respondents said habits of the people, 287 respondents financial incentives, 26 respondents regulations and standards, and only 6 respondents considered that the design of work processes significantly affect on energy efficiency. Answers are presented in the following graphic.

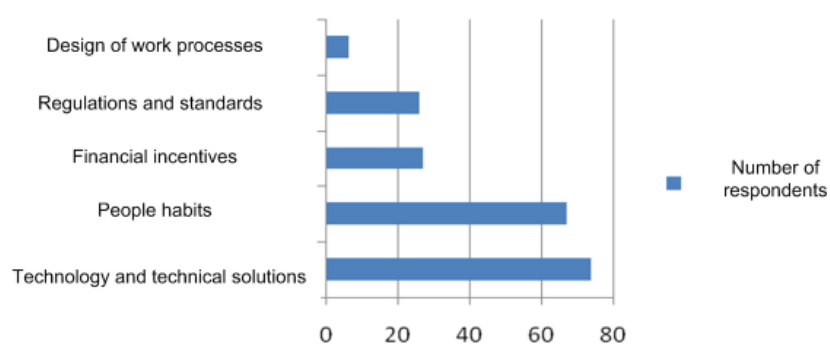

Figure 11: Factors which effect on energy efficiency

10) Familiarity with funds to encourage and assist in the implementation of projects in the field of energy efficiency

Funds for the encouragement and assistance in the implementation of projects in the field of energy efficiency have been established both at the state level, and in the level of individual companies and NGOs. According to the draft form of Law on rational use of energy, will be formed an Energy Efficiency Fund, which will fund projects that promote energy efficiency. Also, there are funds in the Ministry of natural resources, mining and spatial planning, which is funding projects that improve energy efficiency, although these funds are generally intended for public companies. Within the commercial banks, there are also credit lines to finance energy efficiency projects. For this credit line, basic requirement is to achieve energy efficiency improvements of at least $20 \%$.

Question for respondents was: Do you know that there are funds to finance projects in energy efficiency? 107 respondents said they are not familiar with the existence of funds, and 93 that are familiar. The answers are presented graphically.

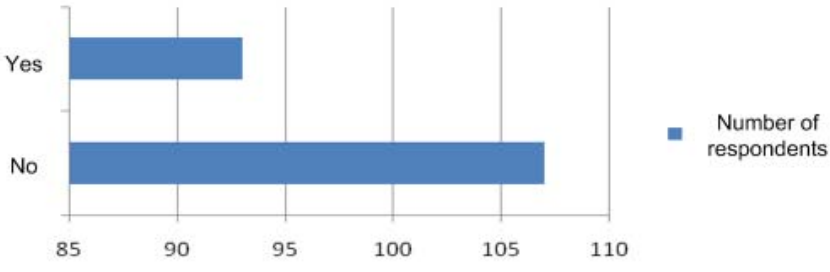

Figure 12: Familiarity with funds to encourage implementation of energy efficiency projects

11) Opinion of respondents about areas in which may be the significant improvements in energy efficiency

The question for respondents was: In what areas would you believe that there may have been significant improvements in energy efficiency? 99 respondents think that the main area of improving is energy production, 77 of respondents believe that is the energy consumption in households, 16 respondents believe that energy efficiency can be improved significantly in transport, and only 8 respondents considered that the improvement in construction and buildings can be significant (although adopted a "package" of legislation in the field of energy efficiency in the construction industry). The answers are presented graphically.

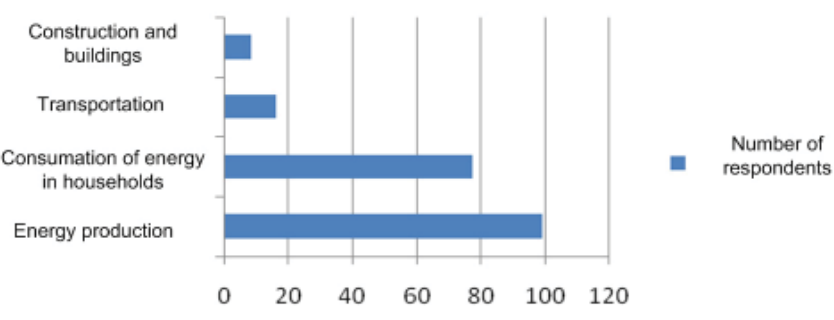

Figure 13: Areas with the significant potential for improvement in energy efficiency

It was investigated how the level of education of the respondents effect visiting conferences, forums and seminars about energy efficiency. How often such events were visited by respondents with high school, college and faculty, is shown below. The results are presented in Figures 14-17.

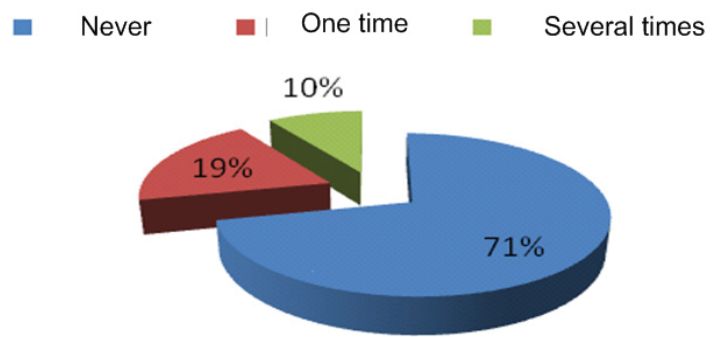

Figure 14: How often respondents with high school visit conferences, seminars and forums about energy efficiency 
- Never

- One time

-

Several times

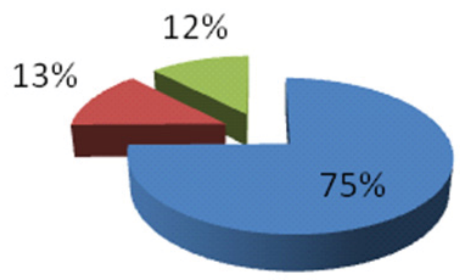

Figure 15: How often respondents with faculty degree visit conferences, seminars and forums about energy efficiency

" Never $=$ Several times $=$ One time $=$ Frequently, always

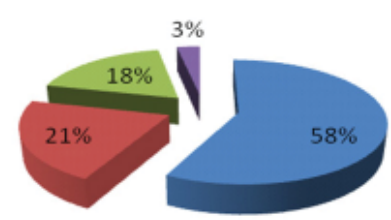

Figure 16: How often respondents with Master degree visit conferences, seminars and forums about energy efficiency

口

Frequently, always a Several times $\square$ Never
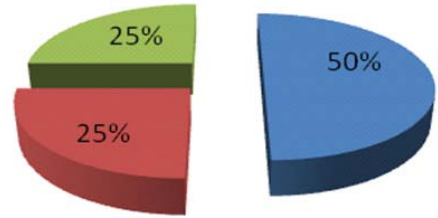

Figure 17: How often respondents with PhD degree visit conferences, seminars and forums about energy efficiency

It has been also investigated how much of respondents which visited conferences on energy efficiency understand the meaning of the term "energy efficiency". The obtained results show that the majority of respondents in this group understand the concept of energy efficiency, however there are respondents which visit conferences, but this term is still not clear for them. The results are shown in Figure 18.

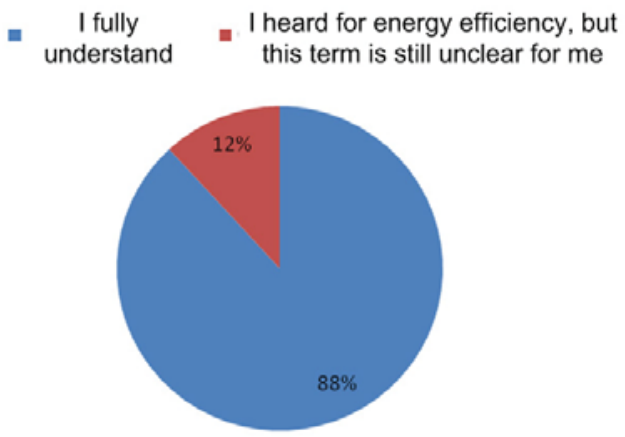

Figure 18: How much respondents which visit conferences, seminars and forums understand meaning of term of "energy efficiency"

Journal of Applied Engineering Science 11(2013)1, 245

\section{CONCLUSIONS AND FUTURE RESEARCH}

Based on collected data in survey, as presented in this paper, the following conclusions were made:

- The majority of respondents were familiar with the concept of energy efficiency, but there is still a large number of respondents who had heard of energy efficiency (probably due to the frequent campaigns on television and in the paper), but do not know what the term means;

- Energy efficiency is an important concept in many areas of human activity (tourism, construction, energy, etc.), but it is not sufficiently represented in the formal education system in the Republic of Serbia;

- In addition to the above, respondents poorly visit meetings with subject of energy efficiency, though in Serbia has a large number and most of them are free;

- The majority of respondents do not know or only superficially are familiar with the new regulations and standards in the field of energy efficiency, which will cover almost every area of work and even everyday life;

- A large number of respondents were aware of the existence of various forms of renewable energy sources;

- The majority of respondents believe that the investment in technology and the changing habits of people may significantly affect the energy efficiency in the territory of the Republic of Serbia;

- Most of respondents were not aware of the existence of funds that are financing projects for improvements in energy efficiency;

- The majority of respondents considered that improvements in production and consumption areas can result in significant improvements in energy efficiency in the future;

- With the higher education level of the respondents, grows interest in visiting conferences on energy efficiency;

- With increasing visits to conferences in the field of energy efficiency, grows the level of understanding of the term "energy efficiency" by respondents.

In future research we will conduct survey on a controlled group respondents, which will be sent 
to the appropriate training in the field of energy efficiency and we will monitor the effect of training. Also, the idea of this paper is to use conclusions in order to create a new subject in faculty, dealing with energy efficiency.

\section{ACKNOWLEDGEMENTS}

This paper is part of a project supported by the Republic of Serbia Ministry of education, science and technological development, under the number III 43008.

\section{REFERENCES}

1) Al-Mansour, F., (2011) Energy efficiency trends and policy in Slovenia, Energy, Volume 36, Issue 4, April 2011, Pages 18681877

2) Backlund, S., Thollandera, P., Palm, J., Ottosson, M., (2012) Extending the energy efficiency gap, Energy Policy, Volume 51, December 2012, Pages 392-396

3) Cagno, E., Worrell, E., Triannia, A., Pugliesea, G., (2013) A novel approach for barriers to industrial energy efficiency, Renewable and Sustainable Energy Reviews, Volume 19, March 2013, Pages 290-308

4) Đajić, N. (2003): Energetika - preduslov održivog razvoja privrede i društva naše zemlje, Journal of Applied Engineering Science, vol. 1, No. 1, pp. 7-14

5) Fleiter, T., Fehrenbach, D., Worrell, E., Eichhammera, W., (2012) Energy efficiency in the German pulp and paper industry - A modelbased assessment of saving potentials, Energy, Volume 40, Issue 1, April 2012, Pages 84-99

6) Griffin, P.W., Hammond, G.P., Ng, K.R., Norman, J.B., (2012) Impact review of past UK public industrial energy efficiency RD\&D programmes, Energy Conversion and Management, Volume 60, August 2012, Pages 243-250

7) Gunn, C., (1997) Energy efficiency vs economic efficiency?: New Zealand electricity sector reform in the context of the national energy policy objective, Energy Policy, Volume 25, Issue 2, February 1997, Pages 241-254
8) http://ankete.izrada-web-sajtova-beograd. com/, downloaded 15.01. 2013.

9) http://www.euractiv.rs, Euractiv Srbija, downloaded 19.11. 2012.

10) http://www.sciencedirect.com, downloaded 02.03. 2013.

11) ISO 50001:2011 Energy management systems - Requirements with guidance for use, International Organization for Standardization, 2011.

12) Law on rational use of energy, draft, Republic of Serbia

13) Lopes, M.A.R., Antunes, C.H., Martins, N., (2012) Energy behaviours as promoters of energy efficiency: A 21st century review, Renewable and Sustainable Energy Reviews, Volume 16, Issue 6, August 2012, Pages 4095-4104

14) Mandal, S.K., (2010) Do undesirable output and environmental regulation matter in energy efficiency analysis? Evidence from Indian Cement Industry, Energy Policy, Volume 38, Issue 10, October 2010, Pages 6076-6083

15) Momčilović, V., Medar, O., Manojlović, A. ,Papić, V. (2003): Povećanje energetske efikasnosti kao element razvoja informacionog sistema transportnog preduzeća, Journal of Applied Engineering Science, Vol. 1, No. 3, pp. 35-43

16) Santos, A.H.C., Fagá, M.T.W., Santos, E.M., (2013) The risks of an energy efficiency policy for buildings based solely on the consumption evaluation of final energy, International Journal of Electrical Power \& Energy Systems, Volume 44, Issue 1, January 2013, Pages 70-77

17) Sola, V.H., Xavier, A.A.P., (2007) Organizational human factors as barriers to energy efficiency in electrical motors systems in industry, Energy Policy, Volume 35, Issue 11, November 2007, Pages 5784-5794

Paper sent to revison: 03.03.2013.

Paper ready for publication: 12.03.2013. 